\title{
A Study on Free Will: Who Sees What in Joseph Conrad's Under Western Eyes?
}

\section{Özgür İrade Üzerine Bir Çalışma: Joseph Conrad'ın Batılı Gözler Altında Romanında Kim Neyi Görüyor? \\ Hilal KAYA*}

\begin{abstract}
The aim of this paper is to explore the art of Joseph Conrad (1857-1924) as an impressionist writer by focusing on one of his novels, Under Western Eyes (1911) as a psychological novel. In order to understand Conrad's motives and style to write this novel one should start with a sound beginning by looking at his concept of narrative fiction and recurring themes in the novel. The points that are highlighted in the paper are the concept of betrayal and its reasons and results for the characters, and the absence of a father as a driving force. Also, such philosophical issues and questions as 'who sees what?', seeing versus understanding and the impossibility of free will be explored in this article. This study argues that Joseph Conrad as a novelist uses impressionism as a tool to capture and convey the psychological principles concerning human consciousness in the aforementioned novel; in this sense, this article is also an attempt to contribute to the scholarship on Conrad's narrative fiction.
\end{abstract}

Keywords: Joseph Conrad, Under Western Eyes, The psychological novel, Impressionism, Free will.

$\ddot{\mathbf{O z}}$

Bu makalenin amacı, bir psikolojik roman olarak Batılı Gözler Altında (1911) adlı eserine odaklanarak İzlenimci (empresyonist) yazar Joseph Conrad'ın (1857-1924) sanatını incelemektir. Romanını yazmaya iten gerekçeleri ve yazarken kullandığ 1 üslubu anlayabilmek için Conrad'ın roman türünden ne anladığını ve romanında tekrar eden temaların neler olduğu incelenmelidir çünkü eserin tahlili için ancak bu yolla doğru bir başlangıç yapılabilir. Bu makalede altı çizilen temel noktalar ihanet olgusu ve ihanetin roman karakterleri için sebep ve sonuçları ve güdüleyen bir güç olarak baba kavramının yokluğudur. Kim neyi görüyor, görmeye karşıt olarak anlamak ve özgür iradenin imkansızlığ gibi felsefi mesele ve sorular da bu makalede tartışılmaktadır. Bu calışma, bir roman yazarı olarak Joseph Conrad'ın, adı geçen romanda, insan bilincine dair psikolojik prensipleri yakalamak ve açığa çıkarmak adına izlenimciliği bir araç olarak kullandığını öne sürmektedir; bu bağlamda, bu çalışma Conrad'ın edebi metinleri üzerine yazılmış olan eleştirel literatüre de katkı sağlamayı amaçlamaktadır.

Anahtar Kelimeler: Joseph Conrad, Batılı Gözler Altında, Psikolojik roman, İzlenimcilik (Empresyonizm), Özgür irade.

\section{Introduction}

Although Joseph Conrad, born in 1857 in Poland, was naturalised as a British citizen in 1886, his own autobiography suggests the importance of his Polish childhood for an understanding of his fiction, describing it as an "inexorable past from which his work of fiction and their personalities are remotely derived" (Conrad, 1912, p.25).

Conrad thinks the writer must appeal to temperament via "an impression conveyed through the senses... because temperament, whether individual or collective, is not amenable to persuasion" (Conrad, 1919, p. ix). For Conrad, an artist/writer:
appeals to that part of our being which is not dependent on wisdom; to that in us which is a gift and not an acquisition-and, therefore, more permanently enduring. He speaks to our capacity for delight and wonder, to the sense of mystery surrounding our lives; to our sense of pity, and beauty, and pain; to the latent feeling of fellowship with all creation-and to the subtle but in - vincible conviction of solidarity that knits together the loneliness of innumerable hearts, to the solidarity in dreams, in joy, in sorrow, in aspirations, in illusions, in hope, in fear, which binds men to each other, which binds to-ether all humanity-the dead to the living and the living to the unborn. (Conrad, 1919, p. viii)

Conrad, in the Preface of The Nigger of the Narcissus (1919), underlines the significance of "the translation of the artist's sense perceptions into vivid and evocative language" (Watt, 1979, p. 160). Therefore, many critics regard Conrad as an impressionist writer. Impressionism is a term applied to the new art of the 1870s and 1880s associated particularly with the

* Dr. Öğr. Gör., Ankara Yıldırım Beyazıt Üni., Yabancı Diller Yüksekokulu, hkaya@ ybu.edu.tr. 
work of French painter Claude Monet. Yet, "it was soon applied to writers whose work seemed to possess the qualities commonly associated with impressionist art, to works that were spontaneous and rapidly executed that were vivid sketches" (Middleton, 2006, p. 17). According to Watt, in literary impressionism, "the stress upon the confused understanding of the individual and the related emphasis on the psychological as opposed to the social marked an important divergence from realism" (1979, p. 171). Because Conrad pays much attention to presenting the subjective aspects of individual experience, he is considered an impressionist writer.

In this sense, it can be argued that, according to Conrad, fiction is a product of imagination or impressions made by the author's first-hand experience. His understanding of the novel is explained as in the following: "[A] novel as a form of imagined life clearer than reality and whose accumulated verisimilitude of selected episodes puts the shame the pride of documentary history" (Conrad, 1912, p. 15). In this assertive argument, Conrad suggests that fiction is "clearer than reality" because it works via selection as opposed to the strict chronology of a "documentary history".

Under Western Eyes (1911) is Conrad's one of the most popular novels in that "it most clearly opposes human relations and emotions against fixed ideas" (Peters, 2006, p. 88). To begin with, several circumstantial factors urged Conrad to write the novel. His visit to Geneva in 1895 provided the idea from which Under Western Eyes initiated. During his stay, Conrad had the chance to make a contrast of Geneva and St. Petersburg. Thus, he based the novel's plot and its argumentative clash between the West and East upon his contrasting impressions in Geneva. As Carabine also suggests, "Conrad's awareness of the disparity between the bourgeois respectability of Geneva and the fervid hopes and conspiracies of the Russian exiles may also have stirred that sense of bewilderment all mittel-Europeans feel when they experience the 'liberty' of the West after escaping the long shadow of Russia" (1996, p. 7).

Basically, Under Western Eyes is about a young man Razumov and his struggles against his own conscience. As a friend of another young revolutionist Haldin who is engaged in violent activities like murdering politicians for the sake of the revolutionary cause. Razumov betrays Haldin and turns him in to the Russian authorities. After this betrayal, Haldin is found guilty and immediately hanged. Betraying his friend causes Razumov to question his ideas, feelings, his sense of future, and eventually even his own existence. When he meets Haldin's sister, Natalia, he immediately falls in love with her and cannot bear the burden of his heavy heart. He begins to suffer from psychological instability, and at the end of the novel, he decides to punish himself and out of the redemptive urges and suicidal tendency, he ends up a cripple in the novel. So, what is underlined by Conrad in Under Western Eyes is the psychological states of characters. For Conrad, two purposes of the novel are "to examine the psychology of betrayal in relation to the inner lives of those affected by Razumov's actions and to gauge the effects of these actions in relation to the condition of Razumov's soul" (Panichas, 2005, p. 80). Thus the rest of the study focuses on the themes in Under Western Eyes arguing that Conrad makes use of literary impressionism to underline the thematic psychological principles reflected in the novel.

\section{The Concept of Betrayal and its Reasons and Results}

The driving force of Conrad's Under Western Eyes deals with the protagonist's, Razumov's, actions of betrayal and eventually his desire for redemption. In his occasion, the act of betrayal is a product of consciousness. If Razumov felt a moral bond with Haldin, he would not betray him. On his way to give away his fellow student, Razumov questions the idea of betrayal: 


\begin{abstract}
'Betray. A great word. What is betrayal? They talk of a man betraying his country, his friends, his sweetheart. There must be a moral bond first. All a man can betray is his conscience. And how is my conscience engaged here; by what bond of common faith, of common conviction, am I obliged to let that fanatical idiot drag me down with him? On the contrary-every obligation of true courage is the other way.' (Conrad, 2008, p. 49)
\end{abstract}

After he gives away Haldin, Razumov must face the consequences of his conscious betrayal. As Panichas puts, this betrayal of Razumov "ignites a cruel process of inner turmoil, moral confusion and death" (2005, p. 80).

\title{
The Absence of Father as A Driving Force for Betrayal
}

Razumov's state of mind and his reasons for betrayal are constantly revealed through information from his diary. From the very beginning to the end of the novel, Razumov is depicted as an isolated young man. His parentage is not clearly known. The narrator states, Razumov is a "young man of no parentage" (Conrad, 2008, p. 12) and "the word Razumov was the mere label of a solitary individuality. There were no Razumovs belonging to him anywhere. His closest parentage was defined in the statement that he was a Russian" (Conrad, 2008 , p. 12). It is said that he is the illegitimate son of a distinguished nobleman Prince $\mathrm{K}-$, who is also his protector. His isolation forces him to try hard and be successful in the world at all costs. He wants to reintegrate to Russian society by winning the silver medal in the essay contest. If he holds the medal, he thinks, it will be a sign which proclaims his status, makes him important in the eyes of others and rescues him from anonymity. "Distinction would convert the label Razumov into an honoured name" (Conrad, 2008, p. 15). Therefore, for him, "the medal is a solid beginning" (Conrad, 2008, p. 15). Although he is silent now, the medal will provide him with the guarantee of his access to language. He will confidently claim and insert his existence in the Russian society.

His sense of being alone renders every way possible and permissible. Therefore, at the beginning of the novel Razumov thinks that being a part of any revolutionary activity brings no good but more sorrow: "He was a Russian: and for him to be implicated meant simply sinking into the lowest social depths amongst the hopeless and the destitute- the night birds of the city" (Conrad, 2008, p. 33). As it is mentioned in the Author's Note in the novel, Razumov is a junior student of St. Petersburg University at the Department of Philosophy and he is also a very promising student. A person who has concerns about and high expectations for his future.

As West remarks, "the lack of paternity... sets the individual outside of social groups and obliges him to devise a new relationship to language and society" (1996, p. 106). Therefore, he is so preoccupied with his academic career that when he learns the crime of Haldin in his room, the first thing he worries about is a potential loss of the silver medal that he could get if he wrote the prize essay. In this sense, the existence of Haldin is a huge threat for him and his life for which Haldin can be regarded as an 'intruder'. Besides, about the betrayal of Razumov a religious analogy is suggested in the novel: Razumov is likened to one of the apostles of Christ, Judas, who is believed to have betrayed Christ. "Even amongst the Apostles of Christ there was found a Judas" (Conrad, 2008, p. 162) ... "He [Haldin] may have been betrayed by some false friend or simply by some cowardly creature" (Conrad, 2008, p. 164). In order not to turn back to his earliest state, isolation, and to protect him from a worse exclusion from society, a political exile, he turns to autocracy. Thus, in his diary he writes as follows:

History not Theory.

Patriotism not Internationalism.

Evolution not Revolution. 
Direction not Destruction.

Unity not Disruption. (Conrad, 2008, p. 91-2)

As mentioned before, on his way to give away Haldin, Razumov ponders on the idea of betrayal. In his inner monologues, he wants to justify his actions:

\begin{abstract}
'What is this Haldin? And what am I? Only two grains of sand. But a great mountain is made up of just such insignificant grains. And the death of a man or of many men is an insignificant thing. Yet we combat a contagious pestilence. Do I want his death? No! I would save him if I could - but no one can do that - he is the withered member which must be cut off. If I must perish through him, let me at least not perish with him, and associated against my will with his sombre folly that understands nothing either of men or things. Why should I leave a false memory?'
\end{abstract}

It passed through his mind that there was no one in the world who cared what sort of memory he left behind him. He exclaimed to himself instantly, 'Perish vainly for a falsehood!... What a miserable fate!' (Conrad, 2008, p. 48)

Evidently Razumov tries to justify his decision of betrayal at the beginning. He wants to get rid of Haldin and does not want to ruin his promising future. Ironically enough, his efforts to save himself does not make him happy at all. They bring forth more misery, rather than a happy life. He wants to join neither of the groups in Russia, neither Revolution nor Autocracy. When Razumov turns in Haldin, he inevitably turns out to be a spy for the Tsarist regime, and makes his way to Geneva. On the contrary to what Razumov expects in life, he reluctantly makes an alliance with the opposite group, autocracy. He gets rid of a Revolutionist and becomes a representative of autocracy. As a spy of Tsarist regime, his duty in Geneva is living with revolutionists and pretending to be one of them in order to learn their secret plans against regime.

In Geneva Razumov meets Haldin's mother and sister, Natalie. His sense of guilt brings him closer to Natalie and, as mentioned before, he falls in love with her. Before they met in person, Razumov's name was already mentioned in the corresponding between brother and sister. West explains the reason why Razumov is attracted to Natalia and asserts that "in revenge, Razumov intends to 'steal' Natalia and to marry her under false pretences; thus, he will pay back Haldin for destroying his hopes of social success" (1996, p. 112). However, when they meet in Geneva, he becomes so fond of Natalia that he states, "[Natalia was] appointed to undo the evil by making [him] betray himself [Razumov] back into truth and peace" (Conrad, 2008, p. 99). After their second meeting, Natalia thanks Razumov as he "understands her" (Conrad, 2008, p. 149). At that moment, Razumov is sure that Natalia, his love for her, is his only chance through which he can find the family or community that he has been missing for years. To Razumov, she is the only person who can finally understand him. "Do you know why I came to you? It is simply because there is no one anywhere in the whole great world I could go to. Do you understand what I say? Not one to go to" (Conrad, 2008, p. 495). Natalia's trust in Razumov poses a contradiction to the previous part of the novel. His love for her is so powerful that it makes Razumov constantly restless about his betrayal and he eventually confesses the role he played in her brother's death. His quiltstricken conscience does not let him be happy and free as it is narrated below:

It was just when he believed himself safe and more - infinitely more - when the possibility of being loved by that admirable girl first dawned upon him, that he discovered that his bitterest railings, the worst wickedness, the devil work of his hate and pride, could never cover up the ignominy of the existence before him. There's character in such a discovery. (Conrad, 2008, p. 495)

Razumov, therefore, decides to confess and relieve his soul and conscience by giving his diary to Natalie although his confession means the destruction of his love: 
I felt that I must tell you that I had ended by loving you. And to tell you that I must first confess. Confess, go out-and perish.

'Suddenly you stood before me! You alone in all the world to whom I must confess. You fascinated me-you have freed me from the blindness of anger and hate-the truth shining in you drew the truth out of me. Now I have done it; and as I write here, I am in the depths depths of anguish, but there is air to breathe at last-air! And, by the by, that old man sprang up from somewhere as I was speaking to you, and raged at me like a disappointed devil. I suffer horribly, but I am not in despair. There is only one more thing to do for me. After that -if they let me-I shall go away and bury myself in obscure misery. In giving Victor Haldin up, it was myself, after all, whom I have betrayed most basely. You must believe what I say now, you can't refuse to believe this. Most basely. It is through you that I came to feel this so deeply. (Conrad, 2008, p. 506)

At the end of the novel, Razumov confesses his guilt and tries to purify his soul. "IIt's myself whom I have given up to destruction,' thought Razumov" (Conrad, 2008, p. 477). In spite of the destruction of his love and life, Razumov at last starts to feel pure love and compassion and because they are so precious to him, he does not want to defile such feelings by keeping the truth as a secret. As Panichas claims, "during his journey of moral discovery Razumov also finds his soul, which talks to him, prods him, heels and redeems him... His experience is one of self-purgation and self-discernment. For Razumov, this is a penitential struggle that mobilizes an inherent capacity for moral growth and cleansing" (2005, p. 98). The novel is about a person who makes a mistake, matures and has to pay the price for such a self-discovery at the end.

\section{Who 'Sees' what in Under Western Eyes}

At the very beginning of the novel, the reader encounters a narrator who uses the pronoun 'I' for his narrative. He introduces himself as an old language teacher. He is both a narrator and a character in the novel. Like most first-person narrations, Under Western Eyes is in the form of a narrative masquerade, in other words, the writer's assumption of a disguise. The writer pretends to be one of the characters, telling a "true" story he has invented. Through this narrator, the reader gets to know Razumov whose diary entries will be read by the reader as well. "It would be idle to inquire why Mr. Razumov has left this record behind him. It is inconceivable that he should have wished any human eye to see it" (Conrad, 2008, p. 3). The language teacher clarifies in his opening remarks that the narrative to follow is based on the writings of the narrative's protagonist, Razumov. However, the language teacher, in fact, has already existed as a character in Razumov's diary before Razumov exists as a character in the 'old Englishman's narrative. This is a metafictional structure in which a story is depicted in another one. Thus, the reader can see the narrator through eyes other than those of the narrator himself. As Rimmon-Kenan defines 'extradiegetic narrator' is on 'the highest level which is the one immediately superior to the first narrative and concerned with its narration. The narrator is, as it were, above and superior to the story he narrates" (1983, p. 95). In this sense, at the beginning of the book, the teacher of languages in Under Western Eyes is an extradiegetic narrator because he is unnamed, very 'English,' has a matter-of-fact voice and mostly points to the historical and social context in which moral decisions facing Razumov made.

Having a language teacher as the narrator of the novel, Conrad also emphasizes the problematic nature of language and brings a self-reflexive mode to the novel. In the course of the novel, the narrator becomes an intra-homodiegetic narrator which is a type of narrator who takes part in the story he narrates. The language teacher is a narrator who has a Western perspective; therefore, his narration can not be regarded as a reliable one due to its limitedness. 
That is why, he intentionally repeats that he is unfamiliar with the Russian way of life and has no intention of understanding it.

The novel's focal character, Razumov is described as one of the 'damned souls' of St. Petersburg. He is one of "the people who have no where to go and nothing to look forward to in this life" (Conrad, 2008, p. 212). He is nearly identity-less, illegitimate son of vague noble connection. A Shakespearean Hamlet-like character, a Dostoevskian Underground or Superfluous man, Razumov is a detached and unformed university student. He longs for being distinctive and recognised in the society of St. Petersburg by becoming a university professor. Yet, this promising young man's life is shuttered one day with the intrusion of Haldin.

The narrator whose narration depends on the journal of Razumov is known to be an Englishman, the teacher of languages. The teacher maintains that "approaching this part of Mr. Razumov's story, my mind, the decent mind of an old teacher of languages, feels more and more the difficulty of the task" (Conrad, 2008, p. 93). He obviously takes this narration as a task for him which is addressed to "the Western readers" (Conrad, 2008, p. 157). He even clearly states his opinion about this task as follows:

If to the Western reader they [incidents happening in Russia] appear shocking, inappropriate, or even improper, it must be remembered that as to the first this may be the effect of my crude statement. For the rest I will only remark here that this is not a story of the West of Europe. (Conrad, 2008, p. 32)

He even goes on judging the case of Razumov according to his Western logic by stating that "nations, it may be, have fashioned their governments, but the governments have paid them back in the same coin. It is unthinkable that any young Englishman should find himself in Razumov's situation" (Conrad, 2008, p. 32). Melnick's consideration on this narrator is as follows: "His [Razumov's] Dostoevskian journal is fragmented, provisionally withheld, filtered, and 'translated' by still another character and narrator in the novel, an Englishman, a language professor" (2001, p. 234). The novel's narrative structure ironically juxtaposes Razumov's Dostoevskian confession with the British professor's narration and translation of that narrative. "A Slavic narrative form is paired against and interacts with a more traditional, conventionally Western version of the novel genre, and a mutually deconstructive tension results, measuring Eastern and Western rhetorics against each other" (2001, p. 238) declares Melnick about this issue.

Even Razumov and the other Russians depicted in the novel exist in submission to the translating language of the Englishman's Western eyes. However, this professor of languages is himself questioned by Conradian irony, which brings forward his rationalistic and sentimental reductions of what he narrates. In this manner, Conrad tests the Professor's sense of individual reason, freedom, will and love. "The teacher's effort to persuade his readers of his honesty, however, suggests his insecurity that causes the reader to suspect his credibility" (Hamilton, 1995, p. 139). While Razumov is the object of the language teacher's gaze, the language teacher is the object of not only the reader's but also Razumov's gaze. Razumov's description of the language teacher occupies an important place in both the language teacher's and Razumov's documents. The following quotation is the narrator's assumption of himself in Razumov's gaze:

The attempted smile was given up, the incipient frown was checked and smoothed so that there should be no sign; but I [the teacher] imagined him [Razumov] exclaiming inwardly_- Her [Nathalie] confidence! To this elderly person - this foreigner!'... 'A foreigner! Talking about an admirable Russian girl. Is the admirable girl a fool, I [Razumov] begin to wonder? What are you at? What is your object?' (Conrad, 2008, p.251-259) 
Razumov's description of the language teacher attracts further attention as depicted in the following: "What devil put him [the language teacher] in the way? I treated him cavalierly enough? Haven't I just? That's the way to treat these meddlesome persons. Is it possible that he still stands behind my back, waiting?" (Conrad, 2008, p. 279). It is not only the professor who is interrogated by the implied narrator in the novel but the readers' conception of Western thought is also exposed to another consideration in the course of the novel. The reader's view of the reciprocal gaze to which the language teacher and Razumov subject one another also implicates that the reader is within the circle of scrutiny as well. The language teacher continually interprets his reader's reactions: "The Western readers for whom this story is written will understand what I mean" (Conrad, 2008, p. 157) and adds that.

\footnotetext{
I wanted to bring it forward simply to make what I have to say presently of Mr. Razumov's presence in Geneva a little more credible - for this is a Russian story for Western ears, which, as I have observed already, are not attuned to certain tones of cynicism and cruelty, of moral negation, and even of moral distress already silenced at our end of Europe. (Conrad, 2008, p. 230)
}

Gaining a view of the characters as they appear to the Western eyes of the old language teacher is Conrad's one of the primary aims in the narration. The narrator remains more or less static during the course of the novel; nevertheless, he proves to be a very useful tool as he functions as a chorus or as a confidant to Natalia. By ending Part One with the question of policeman, Mikulin; "Where to?" and then shifting the narrative to Geneva where Razumov becomes a spy of the autocratic Russia, Conrad creates a sensation of vertigo to produce a contradictory and even a self-destroying narrative structure for the reader. Moreover, the next contradictory narrative structure is also employed by situating Razumov under Rousseau's statue. Like a man who sold his soul to devil, he feels to betray his own self and feelings. Razumov can now see how he is turned into a tool or even a fool in the game of politics.

\section{Seeing vs. Understanding}

Unlike an Eastern man, as underlined before, the narrator is an Englishman who is a man of letter, and Razumov apprehensively inquires if "he [could] have been the devil himself in the shape of an old Englishman" (Conrad, 2008, p. 504) The narrator keeps seeing/searching for a key-word to depict the conditions of his environment. He constantly tries to interpret Razumov but he fails. Moreover, not just the narrator, whoever tries to interpret Razumov fails in the novel. Szittya takes the idea of understanding in the novel futher and asserts that

\footnotetext{
the novel is consequently suffused with the language of interpretive failure-the mysterious, imperceptible, inconceivable, incomprehensible, mystical, strange, dark, obscure. Indeed, Conrad's sense of reality in all his writings seems heavily involved with our inability to understand. (1981, p. 829-830)
}

The diary of Razumov clearly shows his attempt to be understood. It is a possibility of contact in a world of numbing realities and lies. Ironically enough, Razumov, through confession, tries to contact the very persons he has betrayed. At the end of the novel, he becomes deaf (beaten by Nikita), but he finally exists in a world of silence instead of hearing in a totalized society. Hence, he is contacted, cared for by Sophia, Nathalie and Tekla (the lady companion of Madame de S----). He at last becomes a meaningful speech for the alienated outsiders. His silence produces meaning for them. On this issue, Melnick states that

Conrad writes that - in the face of societal delusion and oppression - it is only by using 'our sympathetic imagination' that we may glimpse the possibility of any 'triumph of concord and justice. In the end, Razumov and his listeners inhabit the land of the silenced where they struggle to imagine of what community, freedom, truth, and justice might be. (2001, p. 239) 


\section{The Question 'Where to?' and (Im)possibility of Free-will}

"Conrad employs individual characters to comment on humanity as a whole, and in Under Western Eyes we see the workings of Conrad's view of the universe and the nature of human existence as well" (Peters, 2006, p. 89). The careful reader in the book senses the ongoing fight between human being's free-will and fate. What Conrad wants to underline is that no matter how hard one tries to escape mishaps in life, their fate will find them and make them live whatever planned for them. This is the case for Razumov in the novel. It is hard times for Russia and the atmosphere of suspicion surrounds all Russian society. Therefore, when Haldin appears in his room, Razumov does not want to get involved in any trouble, so he decides to betray him. He freely chooses to betray Haldin and assumes that he can control his fate. In such a society, he cannot avoid involvement. While he wants to avoid the fate, he feared he would end up worse. And that becomes his case when "his career is ruined, and he becomes a haunted creature" (Peters, 2006, p. 89) at the end of the novel.

In Bakhtinian terms, Razumov goes through a "decrowning" in the process of the novel. "Decrowning is a[n] ... ambivalent ritual, expressing the inevitability and at the same time the creative power of the shift-and-renewal, the joyful relativity of all structure and order, of all authority and all (hierarchical) position" (Bakhtin, 1984, p. 124). By means of an allusion to "the Mephistophelian laughter" (Conrad, 2008, p. 83) in his dream, Razumov is mocked and laughed at. As Yilmaz maintains, "when the act of decrowning takes its place in a literary work it loses its image of a mock king's physical decrowning. Yet, at least, it keeps the nature of being loud and visible to everybody" (2018, p. 504). In Razumov's case, his decrowning is eventually witnessed by every character in the novel. This dream symbolizes Razumov's ruined hopes, dreams and unstable state of the soul as a result of his betrayal and consequent failure.

Another part of the novel in which he is in the hands of merciless fate is the part where he lives in the same city with Natalie Haldin. All these misfortunes come together and demonstrate how Razumov is desperate and how he lacks control over his existence. As Natalia describes many Russian young men epitomized in Razumov "unfit for action and yet unable to rest" (Conrad, 2008, p. 237). In the end, he cannot change anything as Peters also clearly puts as follows:

Like Razumov, human beings find themselves in a world in which they believe they can control their lives, but in reality, political and social entities eliminate much of their ability to do so, and, even more disturbing, human beings have no control over what events will occur that may draw them in and forever alter their existence. This theme appears frequently throughout Conrad's writings. (2006, p. 90)

After his betrayal and being a spy for autocracy, Razumov is asked 'where to?' by the police officer Mikulin. This climactic moment in the novel is quite crucial and it reveals the problem of impossibility of the free will. This problem stems from the impossibility to escape the choice between the two powers in Russia, autocracy and revolution. Conrad injects into the Mikulin-Razumov interview the cruel politically realities of an autocracy. Gurko maintains that "the Russia which encloses [Razumov] has already been presented to us an organism different from our own. It is everything Western Europe is not, and when seen under Western eyes appears illogical, arbitrary, baffling, ruled by an uneasy despotism prostituting the ablest impulses of its oppressed subjects to the lusts of hate and fear" (1960, p. 447).

Razumov is so terrified during the interview that he imagines "his own brain suffering on the rack - a long, pale figure drawn asunder horizontally with terrific force in the darkness of a vault" resembling "some dark print of the Inquisition..." (Conrad, 2008, p. 123). 
Razumov's fears reflect the political peculiarities and dilemmas of the country. Autocracy represses ideas, and in this way, it guarantees its existence. Therefore, the idea of retirement that Razumov desires for his future is impossible in the Russia that Conrad draws in his novel. Mikulin's question "where to?" (Conrad, 2008, p. 140) implies that he knows that there is nowhere to go to psychologically, and there is no liberty, even for a loyal Russian. Razumov is torn apart by the ceaseless war between equally lawless antagonisms, which are revolution and autocracy. That is why, the question "where to?" is ironically asked to Razumov as it is apparent that there is no where to go to.

Razumov, in other words, understands different situations he has not been familiar with until that moment when the question "where to?" is raised. As Gurko remarks, "the name Razumov, in both Polish and Russian, means 'to understand,' [and accordingly,] Razumov's journey through the novel is an exercise in understanding" (1960, p. 448). What is expected to be understood by Razumov is that

\footnotetext{
Excessive isolation leads to moral collapse, a purely egoistic attachment to society compels betrayal; a quid pro quo with the world in terms of unselfish response is not a guarantee of sanity and endurance but an indispensable preliminary to them; this response does not destroy selflove but tempers and sophisticates it to the point where the tensions of living inside the ring of an inscrutable cosmos are made. (Gurko, 1960, p. 448)
}

As a conclusion, along with this sense of understanding, Razumov experiences other epiphanies or awakenings, too. Through these newly-learnt lessons of Razumov, Conrad also conveys his other messages such as the unfulfilled human being, the morality of isolation, ecology as a weapon in art, the cycle of betrayal and redemption, the narrator who is also a major actor, the interplay of human beings and society. At the end of the novel, Conrad underlines his widely-known moral message which is that "all a man [sic] can betray is his own conscience" (qtd. in Gurko, 1960, p. 449). This study has attempted to argue that in Under Western Eyes, Joseph Conrad uses literary impressionism as a means to employ the psychological and philosophical questions and principles. The article has foregrounded the psychological questions raised and studied in the novel: they are the concept of betrayal and its reasons and results for the characters, and the absence of a father as a driving force and, such philosophical questions as 'who sees what?', seeing versus understanding and the impossibility of free.

\section{References}

Bakhtin, M. (1984). Problems of Dostoevsky's poetics. Emerson, C. (Ed.). Minneapolis: University of Minnesota Press.

Carabine, K. (1996). The life and the art: a study of Conrad's Under Western Eyes. Amsterdam-Atlanta: Rodopi.

Conrad, J. (1912). A personal record. Najder, Z. and Stape, J. H. (Eds). Cambridge: CUP.

Conrad, J. (1919). Preface. The nigger of the Narcissus: a tale of the forecastle: volume 23 of complete works. New York: Doubleday.

Conrad, J. (2008). Under western eyes. [1911]. New York: ReadHowYouWant.

Gurko, L. (1960). Under Western Eyes: Conrad and the question of "where to?". College English, 21(8), 445-452. doi:10.2307/373158.

Hamilton, A. (1995). The construction and deconstruction of national identities through language in the narratives of Ngũgĩ Wa Thiong'o's a grain of wheat and Joseph Conrad's Under Western Eyes. African Languages and Cultures, 8(2), 137-151. http://www.jstor.org/stable/1771689. 
Melnick, D. C. (2001). Under Western Eyes and silence. The Slavic and East European Journal, 45(2), 231-242. doi:10.2307/3086326.

Middleton, T. (2006). Joseph Conrad. Oxon: Routledge.

Panichas, G. A. (2005). Joseph Conrad: his moral vision. Georgia: Mercer University Press.

Peters, J. G. (2006). Cambridge introduction to Joseph Conrad. Cambridge: CUP.

Rimmon-Kenan, S. (1983). Narrative fiction: contemporary poetics. New York: Routledge.

Szittya, P. (1981). Metafiction: the double narration in Under Western Eyes. ELH, 48(4), $817-$ 840. doi:10.2307/2872963.

Watt, I. (1979). Conrad in the nineteenth century. California: University of California Press.

West, R. (1996). Conrad and Gide: translation, transference and intertextuality. Atlanta: Rodopi.

Yilmaz, V. B. (2018.) Bakhtinian act of "decrowning" in Virginia Woolf's To The Lighthouse. Manisa Celal Bayar Üniversitesi Sosyal Bilimler Dergisi. 16(3), 501-518. http://dergipark.gov.tr/cbayarsos/issue/39491/465750. 